\title{
Contrastive Analysis of Between Mekongga and English Syntax
}

\author{
Kadaruddin Abdul Kadir \\ English Study Program, Teacher Training and Education Faculty, Sembilanbelas November University of Kolaka, South East Sulawesi, \\ Indonesia
}

\author{
Email address: \\ s.kadaruddin@yahoo.com
}

To cite this article:

Kadaruddin Abdul Kadir. Contrastive Analysis of Between Mekongga and English Syntax. International Journal of Language and Linguistics. Vol. 3, No. 3, 2015, pp. 110-115. doi: 10.11648/j.jill.20150303.11

\begin{abstract}
The contrastive analysis is usually used in a foreign language acquisition research. The contrastive analysis is also used in linguistics level, for instance in morphology, syntax, and semantics. This research was conducted to provide useful information which was expected to give contribution in teaching of English especially at SMAN 1 Wundulako. The result of the research is expected to be useful to improve the teaching of English and to develop teachers' professionalism itself. Other reason for this research is to give benefit for the next researcher. Based on the above statements, the researcher is interested in analyzing the patterns and types of Mekongga language sentences compared to English language sentences; moreover, to overcome problems which was found by the native speakers of Mekongga in studying English language. The design of study was a qualitative descriptive research. The data of Mekongga language sentences were obtained from free stories, linguistic books, informants, and from the researcher itself. The data concerning difficulties which might be faced by the native speakers of Mekongga in studying English language sentences were obtained by carrying out a translation test from Mekongga to English language. Mekongga sentences consist of two types of model, namely kernel sentences and derived or transform sentences. The result showed that the pattern of Mekongga kernel sentences is the same as the English's; however, the patterns of Mekongga derived sentences are different from English sentences. Besides, the use of verbs, auxiliary verbs, article, determiner, noun phrase formulation, possessive pronoun formulation, the using of negative marker, and question words were also become distinctive features for both languages. Those differences become problems faced by the native speakers of Mekongga in studying English language sentences. Based on that, a teacher, particularly English language teacher in Kolaka district, need to improve his/her ability to overcome students' difficulties in studying English, for instance by emphasizing in the presentation at difficult part of the subject matter and on the exercises which was prepared for the students.
\end{abstract}

Keywords: Contrastive, Mekongga, English, Syntax

\section{Introduction}

Indonesian society in general belongs to bilingual society, they master first language (L1) regional language and second language (L2) Indonesian language. nevertheless, the mastery of both languages varies according to Indonesian society development.

Mekongga language is one of the local languages in Indonesia. It has the same status as the other local languages in Indonesia. It is one of the local languages used as a communication tool in Wundulako Sub-district Kolaka city Southeast Sulawesi Province.

English is spoken through out the world. It is taught in all junior and senior high schools as a required subject, even in some elementary schools in Indonesia. It has a position in the educational system in Indonesia. Students from different kinds of level have to learn English because it is also one of selection tests to enter a university. These indicate the importance of English in the educational system in Indonesia.

Teaching English as a foreign language faces some problems. One of the main problems is teaching syntax. Syntax as one of language components is also taught to support writing and speaking skill. Without having good and correct forms, it will bring a bad influence on them.

Mothertongue influences towards foreign language or on the contrary can happen in every system or language element because speaker uses system or mothertongue element in using foreign language. Language system that is used can be in the form of phonological system, morphological system, 
and syntactical system.

Most of students in senior high school especially in Kolaka district are unable to formulate the English syntax correctly because of the interference of their own language, Mekongga syntax system. There are differences between the English and Mekongga syntax which make trouble to the students to make forms English syntax.

\section{Basic Concept of Contrastive Analysis}

Lado (1966: vii) introduces contractive analysis as the plan of the book rest on the assumption that we can predict and describe patterns that will cause difficulty in learning, and those that will not cause difficulty, by comparing systematically the language and culture to be learned with the native language and culture of the student.

Then Lado devolves that the comparison between foreign language and mothertongue is the key word that will determine easy or not that foreign language lesson. Than the elements that differ will be difficult for student. Therefore it will cover differences between foreign language and mothertongue, while person will not expect problem if there similarities between foreign language and mothertongue (Nababan and Subyakto, 1993).

Statement of Lado above, supported by Fries's statement (in Nickel, 1971:1) as follows. "The most effective materials are those that are based upon a scientific description of the language to be learned, carefully compared with a parallel description of the native language of the learner."

Meanwhile, Prawono (1996) proposes that contrastive analysis theory assume that difficulty in learning language basically caused by the different between student's first language system with second language that is studied. Therefore, contrastive analysis attempt to contrast the second language system to find similarity and the difference. The same elements of both languages will facilitates student, while different elements will hindrance in learning.

Often a contrastive analysis of a cultural matter that repeatedly causes cross-cultural misinformation will result in intellectual understanding of what the event or matter means to the other people. Emotional effective realization of what it represents to them may be difficult or impossible to achieveand it need not be sought. Students can dislike something yet understand that the other people do not have the same meaning and feeling. We do not have to be alike to communicate with and even appreciate those who are culturally different (Lado, 1988).

Interference can be predicted or explained by comparing the two languages in question and determining how second language differs from the native language of the learner. Weinrich (1953) says that this type of studying which in modern times was preceded by the work. It is part of applied linguistics, not pure linguistics it also draws much from psychology, sociology, and so forth.

Contrastive analysis makes explicit the differences between two languages Pietro (in Croft, 1980); ideally, it should also list those items which are the same in the two languages, since facilitating positive transfer is important as counteracting negative transfer.

The foreign language teacher who knows the cause of an error is much better equipped to deal with it, both in terms of prevention and correction, than the one who does not. Unawareness of interference means not being able to know what is wrong. But through contrastive analysis the teacher can have a fairly precise idea of what is wrong; as Lado (1957) pointed out, the professionally trained teacher will notice clear, specific distortions, not just a foreign accent or a correct form.

Whitman (1970) noted that contrastive analysis involved four different procedures. The first of these are description: the linguist or language teacher, using the tool of formal grammar, explicitly describes the two languages in question. Second, a selection is made of certain form-linguistic items, rules, structure-for contrast, since it is virtually impossible to contrast every possible faced in two languages. The third procedure is the contrast itself, the mapping of one linguistic system onto the other, and a specification of the relationship of one system to the other. Finally, one formulates a prediction of error or of difficulty on the basis of the first three procedures. That production can be arrived at through the formulation of a hierarchy of difficulty or through more subjective applications of psychological and linguistic theory.

The notion of contrast is basic to contrastive analysis and to any learning. In the second language learner, awareness of contrast leads to understanding, which in turn leads to the avoidance of errors. That contrast is fundamental to learning has been stated by Carrol (in Croft, 1980), who claimed that it is psychologically established fact that the frequency with which an item is practiced precise is not so crucial as the frequency with which it is contrasted with other items with which it may be confused. Contrasts can be interlingual, intralingual, or both; making use of both seems to give the best results.

Interference can be seen as interlingual and intralingual. Interlingual interference is based on differences in categories, constructions, elements, rules, and meanings across languages. Intralingua interference usually takes the form of overgeneralizations from what is already known of the second language, overgeneralizations which are based on second language irregularity, complexities, and asymmetry.

Interference on an interlingual basis can be preclusive interference. Preclusive interference occurs when the lack of something in the native language interferes with or precludes the learning of something in the second language. For example, the lack of articles in Chinese interferes with the learning of the system of articles in English by Chinese speakers. This is true interference, due the relationship of new learning to old knowledge is evident from the fact that speakers of French, German or Spanish have no problem with English articles. Intrusive interference refers to the situation where something in the native language intrudes or appears in the second language, for example, the use of the English Adjective + Noun word order in French as a second language. Many people consider only the intrusive type to be 
interference, but it should be clear from the example given earlier and many other example are possible that preclusive interference is just as much interference as intrusive interference.

Furthermore Tarigan (1992) proposes that differences between both languages that got and produced by contrastive analysis, serve the purpose as a basic in predicts difficulties that faced by student at school, all the more in learn second language.

From the explanation above, we can conclude that the contrastive analysis activity tries to compare the student's first language patterns with second language patterns that be studied student to identify similarities and differences between both languages. Similarities between both languages will simplify student in learning the second language, while differences between both languages will complicate student in learning the second language.

\section{Application of Contrastive Analysis}

Contrastive analysis has considerable number of applications. Among are; Comparing and contrasting first and second language acquisition, the preparation of teaching materials, the presentation of second language materials, understanding the learner, the development of second language, and second language testing.

\section{Syntax}

According to Keraf (1980:153) "Syntax (greek: sun+tettein $=$ arrange together) is part of grammar that study bases and sentence formation process in a language." Based on limitation, knowable that sentence is a biggest unit in syntax and every language has syntax rule aloof that can not just like that applied in other language.

As the opinion proposed by Stryker (1969:21) "Syntax is the study about word combination patterns to form sentence." Based on the opinion, perceivable that found three main aspects in syntax, that is word as smallest element in syntax, sentence as biggest element, and patterns as the sentence arrangement rule.

Ba'dulu (2005) states that syntax is the study of interrelationships of words in words groups. In other words, we can say that syntax is conserned with the structure of word groups.

Verhaar (2004) proposes, in general, the sentence structure consists of composition subject (S), Verb (V), object (O), and adeverb (Adv). Syntax functions that consist of elements SVO, and Adv, be empty boxes or vacant lot doesn't has anything meaning because the vacancy. Those vacant lot will loaded by something that shaped category and has certain part. The example in sentence of Mekongga language, "inaku ari kambo ihawi", in English can trasfered be "I came from the village yesterday". other parts in Mekongga language sentence can moved the place without change grammatical meaning of the sentence. For example phrase "ari kambo" moved to the front become "ari kambo inaku ihawi". The change of position can accepted in Mekongga language. When transfered into the English the result become "came from the village I yesteday" the sentence can not accepted in English grammatical structure. Mean that although the composition of Mekongga language sentence acceptable, but in English the composition can not. so the sentence "came from the village I yesterday" be negative transfer or happen syntax tranfer that has interference.

From the limitations that are proposed by linguists, we can conclude that syntax is a part of grammar that have the character of word combination become gramatical unit that larger ones in the form of phrase, clause, and sentence. On the other hand syntax is a grammar branch that talks about sentence structures, clause, and phrase. Syntax is concerned with the way words (strictly, lexicogrammatical-words) are combined to form sentences. Syntax deals with the way words combine to form sentences.

\section{Mekongga Syntax}

The findings consist of the corpus data were obtained through the informant, documents, and translation result from English to Mekongga and Mekongga to English.

The discussion is organized into three parts, namely: (1) the patterns and kinds of Mekongga sentences, (2) the differences between Mekongga and English Sentences, and (3) the problems were Mekongga native speakers faced in learning English sentences.

\subsection{The Patterns and Kinds of Mekongga Sentences}

Based on the corpus data obtained through the informant and the students translation result, seems that the patterns and kinds of Mekongga sentences as follows:

a. Kernel sentences

The pattern of Mekongga kernel sentences can be formulated as follows: Sent $\rightarrow+\mathrm{S}: \mathrm{N}+\mathrm{P}: \mathrm{V} \pm \mathrm{O}: \mathrm{N} \pm$ Comp: Adv.

1)Iwono lako nekamedi gambara iwingi (He went to theatre last night)

2)I Owi mooli oaso oto wuohu inaso ndau (Owi bought a new car last year)

3)I Trika leu kumikii museum i Jakarta (Trika visited the museum in Jakarta)

4) Ihiro megolu koa oleo Minggu (They play football every Sunday)

5) Oaso salawaiha kadadia ihawi (An accident happened yesterday)

6) Kapala kambo lako iraha amano i Eka (The village chief went to Eka's father's house)

7)I Mila mobasa sura kabara koa mooru-oru (Mila reads newspaper every morning)

8) Pakambo maroa morarai (The villagers cheered)

b. Question or interrogative sentences

The patterns of Mekongga question or interrogative sentences can be formulated as follows:

(1) Sent $\rightarrow+$ QM: QW $+\mathrm{S}: \mathrm{N} \pm \mathrm{P}: \mathrm{V} \pm \mathrm{O}: \mathrm{N} \pm$ Comp: Adv,

(2) Sent $\rightarrow+\mathrm{S}: \mathrm{N} \pm \mathrm{P}: \mathrm{V}+\mathrm{QM}$ : pera $\pm \mathrm{O}: \mathrm{N} \pm$ Comp: Adv. 
1)Hula iehei okopi? (Does he like coffee?)

2)Iwono modama pera ne bank? (Does he work in bank?)

3)Iwono lako pera ne kamedi gambara iwingi? (Did he go to the theatre last night?)

4) Inae Paraside RI? (Who is the President of the Republic of Indonesia?)

5)Inae kiniimu iwingi? (Who (m) did you see last night?)

6) Mbakoe iwono pepaguru bitara Inggrisi? (Why does he study English?)

7) Ohapo inolino minggu telalo? (What did he buy last week?)

8) Nehapo pepokondauano iRika bitara Parancisi? (Where does Rika study French?)

c. Command or imperative sentences

The patterns of Mekongga command or imperative sentences can be formulated as follows:

(1) Sent $\rightarrow$ P: V + O: $N \pm$ Comp: Adv,

(2) Sent $\rightarrow \pm$ Comp: Adv + P: V + O: N.

1)Hunggaio otambo! (Open the door!)

2)Lakoto ipase hende neo! (Go to the market now!)

3)Luakee ooto ha-ha ari garasi! (Take the car slowly out of the garage!')

4) Merareto pokoario damamu! (Finish your assignment quickly!)

5) Iamu tumamboi otambo! (Don't shut the door!)

d. Negative sentences

The pattern of Mekongga negative sentences can be formulated as follows:

Sent $\rightarrow+\mathrm{S}: \mathrm{N}+\mathrm{NM}$ : laa/konolaa/kokilaa/kono $+\mathrm{P}: \mathrm{V} \pm$ $\mathrm{O}: \mathrm{N} \pm$ Comp: Adv.

1)Kokulaa monaa oaso kamara dowo (I don't have a private room)

2)Ihiro konolaa mooki osura (They don't write letter)

3)I Ardi konolaa mokowaliaku (Mr. Ardi doesn't help me)

4) Inggami kokilaa madama ingoni neeno (We are not working at the moment)

5) Juru tulisi konolaa umokiike tamono ano mendetee (The secretary did not write her name carefully)

6)Iwono kono poturu ihawi (He was not sleeping yesterday)

7) Ihiro kono onggo lumeleu nggami satu irai (They will not visit us next yesterday)

8)I Ria kono moia i Kolaka nggauno hopulo tau (Ria has not lived in Kolaka for ten years)

e. Passive sentences

The pattern of Mekongga passive sentences can be formulated as follows: Sent $\rightarrow+\mathrm{S}: \mathrm{N}+\mathrm{P}: \mathrm{V} \pm \mathrm{O}: \mathrm{N} \pm$ Comp: Adv.

1) Nggiroo pokondau pinokondauano i auditoriu (The lecture is presented in the auditorium)

2) Dadio pokondau bitara Inggrisi arioto pinokondauako ne wotu oleo tau telalo (Many English courses were given during the summer last year)

3) Dama mboko meambo nggiroo arioto dumamai otuka (The repair work was done by mechanic)

4) Nggiroo osura onggo neleleako pak pos minggu moatu (The letter will be delivered by the postman next week)
5) Nggiroo odama onggo pinoko ari mohina (The work will be finished tomorrow)

6) Nggiroo lapora ano neoki panitia menggena (The report must be written by the same committee)

7) Iina arioto pinoko dungguako nggiroo kadadia (The mother has been informed about the accident)

f. Complex sentences

The patterns of Mekongga complex sentences can be formulated as follows:

(1) Sent $\rightarrow+\mathrm{S}: \mathrm{N}+$ Mod: $\mathrm{Cl} \pm \mathrm{P}: \mathrm{V} \pm \mathrm{O}: \mathrm{N} \pm \mathrm{Comp}: \mathrm{Adv}$,

(2) Sent $\rightarrow+\mathrm{S} 1: \mathrm{N}+\mathrm{P} 1: \mathrm{V} \pm \mathrm{O}: \mathrm{N}+\mathrm{Rel} \mathrm{Cl} \pm \mathrm{S} 2: \mathrm{N} \pm \mathrm{P} 2$ :

$\mathrm{V} \pm \mathrm{O}: \mathrm{N} \pm$ Comp: Adv.

1)Poiaha laahano moia motuo dahuito (The building where he lives is very old)

2) Koku koluluio oleo laahando teposua inggoo (I never forget the day when I met you)

3) Guru owose mombokondau bitara Inggrisi pindaraako (The professor who teaches English is very excellent)

4) Direktur mokondau hiro padama-dama ehe-ehe leu telaa (The director advised the worker who always come late)

5) Nolako ikandoro arinopo mobasa sura kabara mooru-oru (He went to the office after he had read the newspaper in the morning)

6) Iwono meririkee inano hende inano meririkee iwono (He loves his mother as his mother loves him)

7) Iwono kono pendamo masikola ihawi sabano nomorunggu (He didn't go to the class yesterday because he was sick)

8)I Edi onggo meoto lako iManggasa keno laando otono wula maatu (Edi will drive a car to Makassar if he has a car next month)

g. Compound sentences

The pattern of Mekongga compound sentences can be formulated as follows:

Sent $\rightarrow+\mathrm{S} 1: \mathrm{N}+\mathrm{P} 1: \mathrm{V} \pm \mathrm{O}: \mathrm{N} \pm$ Comp: Adv + Conj $+\mathrm{S} 2:$ $\mathrm{N}+\mathrm{P} 2: \mathrm{V} \pm \mathrm{O}: \mathrm{N} \pm$ Comp: Adv.

1)I Ama laa mobasa sura kabara ronga anadalo laa mepaepae catur (Father is reading newspaper and the children are playing chess)

2)I Ali tetoro mesikola, mano i Amir nolako tuunggee sikolano (Ali quit school, but Amir continued his studies)

3) Otambo-tambo nibukaito ronga toono mombesoro-soro pendamo iuneno (The doors were opened, and the audience came crowding in)

4) Masina kono pinokono meambo, atawa inggami koki toorikee teembe pepakeano (The machine is not rightly adjusted, or else we do not know how to operate it)

5)Kono wali-walino kaa wuolio, mano peohaino taro mbodedeaepono (Not only his friends desert him, but his family also disowned him)

6) Iwono monaa kesugira ronga pabitara toori; ieto nggiroo iwono ano tewuoli meambo (He has wealth and ablest lawyers; therefore his chance acquittal is good)

7) Walimami, ari numaa nggami, ropedandi onggo teposua nggami; manokidunggu ne stasiun, konokinii nehapo laa haro (Our friends, who had preceded us, promised that they would meet us; but when we arrived at the station, 
they were nowhere to be seen)

8) Ana sikola mebarisi laahano bel peia, mano oaso toono tumotoa hiro lako ne kamara galasiro (The pupils line up when the bell rings, and someone monitors them while they go to their classroom)

\subsection{The Different between Mekongga and English Sentences}

Each word or phrase in sentence has function to connect other word or phrase in the sentence. The meaning of function here is interdependence connection between elements of equipment until the equipment becomes a whole to be a structure. The function of main syntax in a language is subject, predicate, object, and complement. Although, those elements do not always go together in a sentence.

Besides kernel sentences, all base pattern constituent order of syntax function at the kinds of Mekongga sentences and English sentences are different.

The differences happened were influenced by filler of syntax function namely word classes or so-called syntax category that must fill every function. Example, in the Mekongga question sentences only use one predicate that filled by verb phrase. By contrast, in the English question sentences, found two predicates where first predicate filled by auxiliary verb and second predicate filled by verb phrase.

The other different happen in the use of verb as filler of predicate, where the verb of Mekongga does not need any changes whenever it used. But the English verbs changes into other forms depend on the subject and English tenses used.

The use of article and determiner also become the contrast of Mekongga and English; where in the Mekongga, article and determiner are not needed. By contrast, the use of article and determiner are much needed in English, where the use of article depends on the noun that follows and determiner is needed to refer to the definite noun

The construction of noun phrase also become differ of both language where in Mekongga, the noun phrase is formed by the formulation: noun + adjective. Whereas in English, the noun phrase is patterned by the formulation: adjective + noun.

Construction of possessive pronoun of both languages is also different; it seems at the construction of possessive pronoun in the Mekongga sentence is arranged by placing the noun followed by its owner, while in English, the construction of possessive pronoun is arranged by placing the noun preceded by its owner.

Something else that distinguishes both languages also seems at the use of auxiliary verb. In Mekongga the auxiliary verb is not needed. For example in formulation of negative sentences only by using negative marker: laa, konolaa, kokilaa, or kono that mean not or in formulation question sentences only by using question words inae, hapo, nehapo, mbe or mbakoe. But in English, the use of auxiliary verb is much needed. For example in formulation of negative sentences, auxiliary verb is used before not, or in formulation of question sentences, auxiliary verb is used before the subject, and the use of auxiliary verb depends on the subject and tenses used.
In English, passive sentences can be constructed by using certain auxiliary verbs and past participle form of verbs, where the auxiliary verbs must meet the subjects and the tenses used. Unlike English, the Mekongga does not use any auxiliary verbs, because to form passive sentences, we need

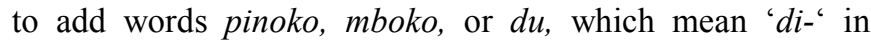
bahasa Indonesia, before the verbs.

\subsection{The Problems Faced by Mekongga Native Speakers in Learning English Sentences}

Based on the data analysis of translation result from Mekongga to English it shown that the different of sentence formulation, the use of verb, auxiliary verb, article, determiner, noun phrase formulation, possessive pronoun formulation, the use of negative marker, and question words are become problems faced by Mekongga native speakers in learning English sentences.

Contrastive analysis result in this research can reveal the differences between Mekongga and English. The differences found in this research can presumably be useful to the English teachers especially in Kolaka district to overcome the difficulties of the student in learning English, for example, they have to give emphasis on their teaching about the difficulties faced by the student and give more practices.

Beside that, the teacher can corrects the students' errors in using English, for instance by correcting the sentence order that uttered by the students in answering the questions given.

The description of constituent order differentiation in the Mekongga sentence and English sentence, also useful to the teacher in orders the lesson matter as the implementation of Garis Besar Program Pengajaran (GBPP) of English subject.

\section{Conclusion}

Based on the research findings and discussion, the researcher puts forward the following conclusion as follows:

1. According to their formation, all of the sentence types discussed can be classified into two main groups: (1) kernel sentences and (2) derived sentences of transform; where kernel sentences have five characteristics: simple, complete, statement, active, and affirmative while derived sentences include questions or interrogative sentences, commands or imperative sentences, passive sentences, negative sentences, complex sentences, and compound sentences;

2. Constituent order differentiation of Mekongga is different from English except at kernel sentences. The other different happen in the use of verbs, auxiliary verbs, article, determiner, noun phrase formulation, possessive pronoun formulation, the use of negative marker, and question words;

3. The Problems faced by the students of Mekongga native speakers in learning English sentences are at the differentiation of sentence pattern, the use of verbs, auxiliary verbs, article, determiner, noun phrase formulation, possessive pronoun formulation, the use of negative marker, and question words. 


\section{Acknowledgement}

Bismillahirrahmanirrahim, Alhamdulillahirabbil alamin. The researcher would like to express his most profound gratitude to Allah SWT, without His Blessing and Mercies upon him, the researcher would have never been able to begin and finish writing this.

My most profound and sincere appreciation goes to his consultant committee, Prof. Dr. Muis Ba'dulu, M.S. and Prof. Dr. Arifuddin Hamra, M.S.Ed. Who have contributed their constructive guidance, available advises, and passionate encouragement in attempting to arrange this research.

$\mathrm{He}$ is also particularly most indebted to the sub district head of Wundulako Jumran, S.Sos and Head Master of SMAN 1 Wundulako Drs. Sulham Landu for his permission and support in carrying out the research. And special thanks to English teacher of SMAN 1 Wundulako Muh. Tang, S.Pd. and his students for his kindness and help until I finish this research and his thanks go to all the informants from Mekongga community who has given serious attention and active participation as the subjects of research.

The researcher would like also to devote his very special thanks to his parents, H. Abd. Kadir and $\mathrm{Hj}$. Ruhini for their sincere prayers for success, and also his beloved wife Emy Alimuddin who always motivates, supports, and prays for the researcher success, and to all his children Eka Annisa Dzulqaidah, Dwika Putra Tzalsa Ramadhan, and Trika Anugrah Sya'ban whose love, care, understanding, prayers, and encouragement were meaningful to the researcher in doing the work.

May Allah the Almighty always be with us. Amen

\section{References}

[1] Ba'dulu, Abdul Muis. 2005. English Syntax. Makassar: Graduate Programme UNM.

[2] Croft, Kennerth. 1980. Reading on English as a Second Language. Cambridge: Winthrop Publishers.

[3] James, C. 1980. Contrastive Analysis. London: Longman.

[4] Keraf, Gorys, 1980. Tata Bahasa Indonesia untuk Sekolah Lanjutan Atas. (Cet. VIII). Ende Flores: Nusa Indah.

[5] Lado, R. 1988. Teaching English across Cultures. United Stated: McGraw-Hill Inc.

[6] Nababan, P.W.J dan Sri Utari Subyakto. 1993. Metodologi Pengajaran Bahasa. Jakarta: Gramedia.

[7] Nickel, Gerhad. 1971. Papers in Contrastive linguistic. London: Cambridge University Press.

[8] Prawono. 1996. Analisis Pengajaran Bahasa. Yogyakarta: Gajah Mada University Press.

[9] Stryker, Shirley L. 1969. "Applied linguistics”; Principle and Techniques Dalam Forum Vol. VII No.5

[10] Tarigan, Henry Guntur. 1992. Pengajaran Analisis Kontrastif Bahasa. Bandung: Angkasa.

[11] Weinrich, M. 1953. Language in Contact. New York: Linguistic Circle of New York.

[12] Whitman, Randal. 1970. Contrastive Analysis. New York: Macmillan Publishing Co., Inc. 